\title{
The silicon isotopic composition of surface waters in the Atlantic and Indian sectors of the Southern Ocean
}

\author{
Christina L. De La Rocha ${ }^{a}{ }^{*}$, Pierre Bescont $^{a}$, Alice Croguennoc ${ }^{a}$ and Emmanuel Ponzevera ${ }^{b}$
}

\author{
a UMR 6539, LEMAR, IUEM, Université de Bretagne Occidentale, Technopôle Brest-Iroise, Place Nicolas \\ Copernic, 29280 Plouzané, France \\ ${ }^{\mathrm{b}}$ IFREMER, Dept. Geosciences Marines, Pointe de Diable, Plouzané, France
}

*: Corresponding author : Christina L. De La Rocha, Tel.: +33 (0) 298498790 ;
emai address : christina.delarocha@univ-brest.fr

\begin{abstract}
:
We report here the silicon isotopic composition $\left(\delta^{30} \mathrm{Si}\right)$ of dissolved silicon (DSi) from 42 surface water samples from the Drake Passage, the Weddell Gyre, other areas south of the Southern Boundary of the Antarctic Circumpolar Current (ACC), and the ACC near the Kerguelen Plateau, taken between the beginning of February and the end of March 2007. From the beginning to end of the cruise (ANTXXIII/9), DSi diminished in the Antarctic by $50 \mu \mathrm{mol} \mathrm{L}^{-1}$ while concentrations of nitrate + nitrite and phosphate showed no net decline, indicating that the high seasonal Si/N removal ratios well known for the Southern Ocean may be more related to the strength of the silicate pump in the Southern Ocean than to the instantaneous Si/N uptake ratio of diatoms. The $\delta^{30} \mathrm{Si}$ of DSi in samples containing more than $20 \mu \mathrm{M}$ DSi were strongly negatively correlated to DSi concentrations, supporting the use of $\delta^{30} \mathrm{Si}$ as a proxy for DSi removal. The "open system" fractionation observed, $\varepsilon=-1.2 \pm 0.11 \%$, agrees well with results from previous work in other areas, and the estimate of the initial $\delta^{30} \mathrm{Si}$ of DSi of $+1.4 \%$ is not far off observations of the $\delta^{30} \mathrm{Si}$ of DSi in Winter Water (WW) in this area. Results were used to model DSi draw down in the past from the $\delta^{30} \mathrm{Si}$ of sediment cores, although isotopic fractionation during silica dissolution appeared to influence the $\delta^{30} \mathrm{Si}$ of some surface water samples, inviting further study of this phenomenon.
\end{abstract}




\section{Introduction}

There is interest in using the silicon isotopic composition $\left(\delta^{30} \mathrm{Si}\right)$ of diatom silica from sediments to reconstruct the percent removal of the nutrient dissolved silicon (DSi) from surface waters in the past (De La Rocha et al., 1998; Brzezinski et al., 2002; Varela et al., 2004; Cardinal et al., 2005; Reynolds et al., 2006; Beucher et al., 2007; Cardinal et al., 2007). Such studies have predominantly focused on the Southern Ocean, where the drawdown of nutrient concentrations in support of primary production may influence both atmospheric concentrations of $\mathrm{CO}_{2}$ and, through the delivery of unutilized nutrients via the thermocline, the ecology and productivity of low latitude upwelling systems (Sigman and Boyle, 2000; Brzezinski et al., 2002; Matsumoto et al., 2002; Sarmiento et al., 2003; Bradtmiller et al., 2007; Crosta et al., 2007).

Conversion of $\delta^{30} \mathrm{Si}$ values of diatoms from marine sediments to nutrient utilization requires knowing several things: the extent of isotope fractionation during biogenic silica formation, the $\delta^{30} \mathrm{Si}$ of DSi upwelling into the euphotic zone, the degree to which the location in question behaves as a perfectly closed system (one input of DSi at the beginning of the growing season) versus a perfectly open system (continuous input of DSi throughout the growing season), and whether or not isotope fractionation occurs during dissolution and diagenesis of the diatom silica.

Progress has been made on several of these issues, but more information is needed for quantitative use of $\delta^{30} \mathrm{Si}$ as a proxy for DSi utilization. For example, culture experiments and field work have revealed that diatom silica is roughly $1.1 \%$ more negative than the DSi supplied (De La Rocha et al., 1997; Milligan et al., 2004; Varela et al., 2004; Cardinal et al., 2005; Reynolds et al., 2006). However, there remains approximately $1 \%$ of scatter about this estimate.

In order to address some of these issues pertaining to using $\delta^{30} \mathrm{Si}$ to understand the silica cycle in the past Southern Ocean, we measured the $\delta^{30} \mathrm{Si}$ of DSi from present day surface waters towards the end of the growing season along a cruise track covering portions of the Atlantic and Indian sectors of the Southern Ocean, sectors that have played host to several of the sediment cores that have been analyzed for $\delta^{30} \mathrm{Si}$ (De La Rocha et al., 1998; Brzezinski et al., 2002). Our aim was to see to what extent the $\delta^{30} \mathrm{Si}$ of DSi reflected the removal of DSi across a large swath of the growing season. We also hoped to compare the relationship between $\delta^{30} \mathrm{Si}$ and DSi in the Atlantic and Indian sectors of the Southern Ocean with that previously observed in the Pacific sector (Varela et al., 2004; Cardinal et al., 2005; 2007).

\section{Study area}

One of the more striking features of the Southern Ocean is the Antarctic Circumpolar Current (ACC), an eastward flowing current of water encircling the Antarctic continent (Orsi et al., 1995). Between its northern boundary (the Subtopical Front, STF) and its southern boundary (the Southern Boundary of the ACC, SB or SBACC), the ACC is comprised of roughly latitudinal zones defined by the similarly circumpolar fronts the Subantarctic Front (SAF) the Antarctic Polar Front (PF) (Fig. 1a). In a general sense, nutrients brought to the surface via the upwelling of Circumpolar Deep Water (CDW) close to the Antarctic continent spread northwards across the PF and into the Subantarctic Zone where they sink to form Antarctic Intermediate Water. 
East of the Antarctic Peninsula, in the Atlantic Sector, the SB of the ACC lies far to the north of the Antarctic continent (Fig. 1a). Filling this large area to the south of the SB in the Atlantic Sector is the cyclonic Weddell Gyre (Klatt et al., 2005). At the eastern end of our study area, lies the Kerguelen Plateau, another area of complex circulation in the Southern Ocean (Roquet et al., 2009). The shallow depths of the Kerguelen Plateau disrupt the eastwards ACC flow, causing the PF to bifurcate, and driving some of the ACC flow north of the plateau and some of it south of Kerguelen and Heard Islands, through the Fawn Trough (Roquet et al., 2009; van Wijka et al., 2010).

\section{Methods}

\subsection{Cruise track and sample collection}

Samples were collected during F.S. Polarstern cruise ANTXXIII/9. This cruise began on February 2, 2007 in Punta Arenas, Chile, crossed the Weddell Sea to the edge of the shelf ice near Neumayer Station, traversed eastwards along the edge of the shelf ice to Prydz Bay, and then sailed up the Kerguelen Plateau and onwards to Cape Town, South Africa, arriving on April 10, 2007 (Fig. 1). The purposes of the cruise were primarily geologicalcollecting sediment cores and conducting geophysical surveys. As such, the cruise was very much one "of opportunity", allowing for only fairly modest geochemical sampling.

Water samples were taken through a "snorkel" extended through the Brunnenschaft, or moon pool, in the ship's hull (Helmers et al., 1991). This snorkel consisted of a 1.5 meter long steel tube extended below the keel. At the tip of the pipe was a teflon "nose" through which water could be taken up cleanly when the ship was steaming faster than 5 knots. This water was taken on board at each sampling location using plastic tubing and a teflon membrane pump and dispensed into clean $20 \mathrm{~L}$ carboys from which subsamples could be taken.

\subsection{Treatment and analysis of samples}

Each water sample was immediately filtered through a $0.6 \mu \mathrm{m}$ polycarbonate filter (GE Water $\&$ Process Technologies/Osmonics). These filters were immediately frozen and stored at $80^{\circ} \mathrm{C}$ for later determination of chlorophyll content. Samples for biogenic silica (BSi) measurements were also taken on $0.6 \mu \mathrm{m}$ polycarbonate filters but were dried overnight at $60^{\circ} \mathrm{C}$ and stored at room temperature until analysis. Samples for concentrations of soluble reactive phosphate $\left(\mathrm{PO}_{4}\right)$ and nitrate + nitrite (NOx) were taken from the filtrate and placed in acid-cleaned LDPE bottles, frozen without delay, and stored at $-20^{\circ} \mathrm{C}$. Filtered samples for DSi concentrations and for the $\delta^{30} \mathrm{Si}$ of DSi were stored at room temperature in acid-cleaned LDPE bottles. All samples were shipped back to Europe for analysis.

Chlorophyll on the frozen filters was extracted in acetone at $-20^{\circ} \mathrm{C}$ after crushing of the cells using glass beads and a shaker. Chlorophyll concentrations of the extract were then measured in a Turner Designs TD-700 fluorometer. Concentrations of $\mathrm{NOx}$ and $\mathrm{PO}_{4}$ in the water samples were made using an autoanalyzer (Technicon ASM II). DSi concentrations were measured manually via molybdate blue spectrophotometry (Strickland and Parsons, 1972). Samples of BSi were digested in $0.2 \mathrm{M} \mathrm{NaOH}$ for 40 minutes at $100^{\circ} \mathrm{C}$ before neutralization and analysis as DSi samples.

Si for the measurement of the $\delta^{30} \mathrm{Si}$ of DSi was extracted from the seawater by precipitating it as triethylamine silicomolybdate and then combusting that to form $\mathrm{SiO}_{2}$ (De $\mathrm{La}$ Rocha et al., 1996). This $\mathrm{SiO}_{2}$ was then dissolved at room temperature in $23 \mathrm{M} \mathrm{HF}$ to yield $0.23 \mathrm{~mol} \mathrm{~L}^{-1} \mathrm{Si}$. This silicon was further purified using an ion exchange column following one of the methods 
outlined in Engström et al (2006). In short, Si was loaded onto columns containing AG 1-x8 resin (BioRad) that had been preconditioned using $2 \mathrm{M} \mathrm{NaOH}$. Samples containing $4 \mu \mathrm{mol}$ Si were loaded onto the columns in $7.7 \mathrm{ml}$ of $52 \mathrm{mM} \mathrm{HF}$. Matrixes were eluted using $95 \mathrm{mM}$ $\mathrm{HCl}+23 \mathrm{mM} \mathrm{HF}$. Purified Si eluted with $0.14 \mathrm{M} \mathrm{HNO}_{3}+5.6 \mathrm{mM} \mathrm{HF}$. Acids used were all Suprapur (Merck) and were diluted with deionized distilled water (18.2 M $\Omega-\mathrm{cm})$.

For $\mathrm{Si}$ isotope analysis on the Neptune multi-collector inductively coupled plasma mass spectrometer (MC-ICP-MS) (Thermo Scientific), Si-containing elutions were diluted with 0.16 $\mathrm{M} \mathrm{HNO}_{3}\left(1 \% \mathrm{HNO}_{3}\right)$ to $2 \mathrm{ppm} \mathrm{Si}$ to yield a roughly $10 \mathrm{~V}$ signal on mass 28 at medium resolution (see Table 1 for additional information on operating conditions). All samples and standards (NBS28 and a 99.995\% pure silica sand (Alfa Aesar) used as a working standard) were matched to give the same signal strength (within 10\%) and to contain the same amount of HF (generally $1 \mathrm{mM}$ ). $\mathrm{Mg}$ was added to the samples and the standards to a final concentration of $0.1 \mathrm{ppm}$. For each measurement, beam intensities at masses 25 and 26 (Mg), and 28, 29, and 30 (Si) in dynamic mode (i.e. switching between $\mathrm{Si}$ and $\mathrm{Mg}$ masses) were monitored for 1 block of 30 cycles of 8 second integrations. Five minutes of rinse with $2 \%$ nitric acid followed each sample and each standard solution.

$\mathrm{Si}$ isotope ratios $\left({ }^{30} \mathrm{Si} /{ }^{28} \mathrm{Si}\right.$ and $\left.{ }^{29} \mathrm{Si} /{ }^{28} \mathrm{Si}\right)$ were corrected for mass bias during the measurement first by $\mathrm{Mg}$-correction (Cardinal et al., 2003). For example, the corrected ${ }^{30} \mathrm{Si}$ to ${ }^{28} \mathrm{Si}$ ratio, $\left({ }^{30} \mathrm{Si} /{ }^{28} \mathrm{Si}\right)_{\text {corr }}$, is

$$
\left(\frac{{ }^{30} S i}{{ }^{28} S i}\right)_{\text {corr }}=\left(\frac{{ }^{30} S i}{{ }^{28} S i}\right)_{\text {meas }} \times\left(\frac{{ }^{30} S i_{A M}}{{ }^{28} S i_{A M}}\right)^{\varepsilon_{M g}}
$$

where $\left({ }^{30} \mathrm{Si} /{ }^{28} \mathrm{Si}\right)_{\text {meas }}$ is the measured ratio, ${ }^{30} \mathrm{Si}_{\mathrm{AM}}$ and ${ }^{28} \mathrm{Si}_{\mathrm{AM}}$ are the atomic masses of ${ }^{30} \mathrm{Si}$ and ${ }^{28} \mathrm{Si}$. $\varepsilon_{\mathrm{Mg}}$ is calculated from the beam intensities on masses 25 and 26 :

$$
\varepsilon_{M g}=\ln \left[\frac{\frac{{ }^{25} M g_{A}}{{ }^{26} M g_{A}}}{\left(\frac{{ }^{25} M g}{{ }^{26} M g}\right)_{\text {meas }}}\right] \div \ln \left[\frac{{ }^{25} M g_{A M}}{{ }^{26} M g_{A M}}\right]
$$

where ${ }^{25} \mathrm{Mg}_{\mathrm{A}} \mathrm{l}^{26} \mathrm{Mg}_{\mathrm{A}}$ is the expected ratio of the natural abundances of the isotopes, $\left({ }^{25} \mathrm{Mg} /{ }^{26} \mathrm{Mg}\right)_{\text {meas }}$ is the measured ratio, and ${ }^{25} \mathrm{Mg}_{\mathrm{AW}}$ and ${ }^{26} \mathrm{Mg}_{\mathrm{AW}}$ are the atomic masses of ${ }^{25} \mathrm{Mg}$ and ${ }^{26} \mathrm{Mg}$.

Each measurement of a sample fell between two measurements of the standard and each sample was measured twice before moving on to the next sample. This total of two sample measurements and three standard measurements was used to calculate three preliminary values of $\delta^{30} \mathrm{Si}$ and $\delta^{29} \mathrm{Si}$ :

$$
\delta^{\mathrm{x}} S i=\frac{R_{\text {sam }}-R_{\text {std }}}{R_{\text {std }}} \times 10^{3}
$$


where $\delta^{\mathrm{x}} \mathrm{Si}$ is either $\delta^{29} \mathrm{Si}$ or $\delta^{30} \mathrm{Si}$, and $\mathrm{R}_{\text {sam }}$ and $\mathrm{R}_{\text {std }}$ are the ${ }^{29} \mathrm{Si} /{ }^{28} \mathrm{Si}$ of the sample and standard (for $\delta^{29} \mathrm{Si}$ ) or the ${ }^{30} \mathrm{Si} /{ }^{28} \mathrm{Si}$ of the sample and standard (for $\delta^{30} \mathrm{Si}$ ).

The average of these three preliminary values was then used as the reported values of $\delta^{30} \mathrm{Si}$ and $\delta^{29} \mathrm{Si}$ (i.e. those in Table 2). The typical precision of each such determination ( $1 \sigma$ standard deviation) was $\pm 0.04 \%$ on $\delta^{30} \mathrm{Si}$. Long term precision (1s SD) on the measurement (including the column chemistry) was $\pm 0.07 \%$ on $\delta^{30} \mathrm{Si}$ (based on 22 separate samples of the standard measured between July 6, 2009 and September 1, 2010). Procedural blanks were typically $0.1 \mathrm{~V}$ on mass $28,0.006 \mathrm{~V}$ on mass 29 , and $0.004 \mathrm{~V}$ on mass 30 , or $1 \%$ of the sample signal.

\section{Results and discussion}

\subsection{Dynamics of DSi, NOx, and $\mathrm{PO}_{4}$}

Between the Drake Passage (February 5) and Prydz Bay (March 8), the concentration of DSi in surface waters along the cruise track decreased from $>70 \mu \mathrm{M}$ DSi down to $\sim 20 \mu \mathrm{M}$ (Fig. 2). This decrease was in part related to the continuing removal of DSi by diatoms as the late summer advanced into autumn (Fig. 2a). It was also a part of the general latitudinal gradient in DSi concentrations in the Southern Ocean as reflected by the surface samples reported here excepting those from the Weddell Gyre (Fig. 2d).

In marked contrast to this, concentrations of $\mathrm{NOx}$ and $\mathrm{PO}_{4}$ in Antarctic portions of the cruise

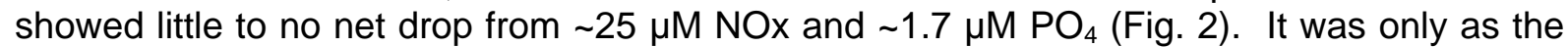
northern limit of the ACC was reached at about $50^{\circ} \mathrm{S}$ at the end of March that concentrations of NOx and phosphate began to decline. By the point that $\mathrm{NOx}$ and $\mathrm{PO}_{4}$ concentrations began to decline steeply, DSi concentrations had more or less already been exhausted.

Such differences in the behavior of DSi and nitrate in the Southern Ocean, and indeed, in the Indian Sector, this exact pattern (Pondaven et al., 2000), have long been noted (e.g., Kamykowski and Zentara, 1989; Brzezinski et al., 2003) and ascribed to various factors. The standard explanation has been that Fe limitation increases the degree of silicification and the instantaneous Si/N uptake ratio of diatoms (Takeda 1998; Franck et al., 2000; Hoffmann et al., 2007). The more refractory nature and thus deeper depth of regeneration for silica compared to organic matter also contributes to the excess removal of DSi over nitrate and phosphate in surface waters, a set of processes referred to as the silicate pump (Dugdale et al., 1995). Grazing pressure may also exacerbate the change in silicification at the community level by favoring the survival of diatoms with more heavily silicified frustules under the low phytoplankton growth rates of the cold, low-light, and Fe limited conditions of the Southern Ocean (Smetacek et al., 2004). Fe limitation may even further enhance the silicate pump by preventing the utilization of nitrate and nitrite but not of DSi (Brzezinski et al., 2003).

The DSi and NOx data presented here are more in line with the interpretation based on the silicate pump rather than on changes to the instantaneous uptake ratio of DSi to nitrate (or phosphate) (Fig. 2). During this latter portion of austral summer, the instantaneous Si/N and Si/P uptake ratios of diatoms had to be either infinite (i.e. only net uptake of DSi occurred) or irrelevant to the observed drawdown ratios of nutrients from surface waters since NOx concentrations showed no net decrease but DSi most strikingly did.

Standing stocks of BSi (and particulate organic matter, at least as reflected by chlorophyll concentrations) did not notably increase in surface waters as DSi concentrations declined some $50 \mu \mathrm{M}$ between the beginning of February and the middle of March (Fig. 3), suggesting that BSi produced from DSi was being exported rather than accumulating. Thus the 
evolution of the nutrient concentrations during the cruise may be due to a strong silicate pump occurring in tandem with the near complete recycling of particulate organic matter in the surface ocean during late summer in the study area. Given the high Si/C and Si/N ratios of predominant Southern Ocean diatoms as Fragilariopsis kerguelensis and frequent observations of their empty frustules, devoid of organic matter, in the water column (Smetacek et al., 2004), it is not implausible that in ecosystems where they dominate, Si is exported while $\mathrm{N}$ and $\mathrm{P}$ tend to be retained in the euphotic zone (Smetacek et al., 2004).

Such decoupling has been seen before. For example, during diatom growth during the month of December 1997 in the Pacific Sector of the Southern Ocean, the gross uptake ratio of $\mathrm{Si} / \mathrm{N}$ (which does not take silica dissolution into account and includes both new and regenerated forms of nitrogen) was observed to be close to 1 mol:mol (Brzezinski et al., 2003), what would be expected for nutrient replete diatom growth (Brzezinski 1985). However, the net Si/N uptake ratio (which took silica dissolution into account and counted the uptake of only new forms of nitrogen, i.e. NOx), at $3.7 \mathrm{~mol}: \mathrm{mol}$, was considerably higher (Brzezinski et al., 2003). This implied more intensive recycling of nitrogen than silica within the euphotic zone, and thus a silicate pump that was stronger than the biological (organic matter) pump. Likewise, while the growth of diatoms on the Kerguelen Plateau occurs with an instantaneous uptake ratio of about 1 for $\mathrm{Si}$ and $\mathrm{N}$, over a season, three times more DSi than $\mathrm{N}$ is removed from surface waters. This is due to the intense recycling of $\mathrm{N}$ relative to $\mathrm{Si}$, causing a decoupling of the silicate pump and the export of organic matter (Mosseri et al., 2008).

Thus we would like to iterate a key point that has been somewhat lost in the interpretation of diatom proxy records from the Southern Ocean: instantaneous ratios of nutrient uptake by phytoplankton in the Southern Ocean are not the same thing as (and are not necessarily the proximal cause of) the ratio of nutrient drawdown over the entire growing season. While net decline of all major nutrients would have occurred in spring and early summer (e.g., as seen in the Weddell Sea through the end of January by Jennings et al., 1984), no singular instantaneous Si/N or Si/P uptake ratio could explain a difference of $50 \mu \mathrm{M}$ DSi coinciding with no net change in NOx or phosphate concentrations (Fig. 2). Such differences are more easily explained by differences in the efficiency of recycling (or export, depending on which side of the coin you prefer to look at) of BSi versus particulate organic matter.

That silica and nitrogen cycling (and silica and carbon cycling) can be decoupled, especially in the Southern Ocean, is not a new idea, nor is the thought that this might make opal accumulation in the sediments an unreliable proxy for carbon flux or productivity (Dugdale et al., 1995; Ragueneau et al., 2002; Smetacek et al., 2004; Abelmann et al., 2006; Ragueneau et al., 2006; De La Rocha et al., 2010a). In addition to the effects of Fe and other types of nutrient limitation on cellular Si/N and Si/C ratios (De La Rocha et al., 2000b; Hoffmann et al., 2007; De La Rocha et al., 2010b), shifts between diatom and Phaeocystis populations, or between diatom populations dominated by highly silicified species with high $\mathrm{Si} / \mathrm{C}, \mathrm{Si} / \mathrm{N}$, and $\mathrm{Si} / \mathrm{P}$ ratios(like Fragilariopsis kerguelensis) and those dominated by lightly silicified species with low Si/C, Si/N, and Si/P ratios (like Chaetoceros sp.), can have a large impact on the gross ratios of nutrient uptake and, in principle, export ratios as well. Thus considerable variability in the gross removal of DSi from surface waters is possible without any change in primary productivity and/or carbon export (Abelmann et al., 2006; De La Rocha et al., 2010a).

The thought that differences in the rates or efficiencies of remineralization of silica versus organic matter can decouple Si from N and C is also not a new one ((Dugdale et al., 1995; Ragueneau et al., 2002; Nelson et al., 2002; Ragueneau et al., 2006). It is well known, for example, that the Si/C ratio of the sinking flux in the ocean increases with depth (Ragueneau et al., 2002; Nelson et al., 2002; Ragueneau et al., 2006) due to the generally more refractory nature of silica than organic matter (Dugdale et al., 1995). Likewise, in the 
southern ACC in the Pacific Sector of the Southern Ocean, the Si/N ratio of material sinking at $1000 \mathrm{~m}$ was recorded at 30 moles Si per mole $\mathrm{N}$, compared to an instantaneous production ratio of $5 \mathrm{~mol}: \mathrm{mol}$ (as calculated from data in Nelson et al., 2002). Given that less than $5 \%$ of biogenic silica produced is preserved in marine sediments (and an even smaller fraction of produced organic matter), it would take only a slight change in remineralization efficiencies to totally change the picture of productivity estimated from the sedimentary accumulation rate. In terms of complicating (or even invalidating) the use of accumulation rates of biogenic silica in marine sediments as a proxy for carbon flux or for primary production, these decouplings during remineralization have long been appreciated. Where they come less (or not at all) in to play is during the interpretation of isotope-based reconstructions of nutrient cycling.

In terms of (stable isotopic) paleoceanographic records based on diatoms, records of the nitrogen isotopic composition $\left(\delta^{15} \mathrm{~N}\right)$ of organic matter trapped within the silica matrix of diatoms are thought to show roughly the opposite of records of $\left(\delta^{30} \mathrm{Si}\right)$ of the silica itself (De La Rocha et al., 1998; Brzezinski et al., 2002; De La Rocha 2006). $\delta^{15} \mathrm{~N}$ is considered to peak at the last glacial maximum (LGM) and decrease towards the Holocene, suggesting that a smaller fraction of available nitrate was used during the growing season moving forward in time from the LGM (Brzezinski et al., 2002 and references therein). $\delta^{30} \mathrm{Si}$, however, shows minimum values at the LGM and higher ones in the Holocene, suggesting an increase in the percent consumption of DSi each growing season moving forward in time from the LGM (De La Rocha et al., 1998; Brzezinski et al., 2002). This marked discrepancy between the two nutrient use proxies has been explained with suggestions that alleviation of Fe limitation at the LGM and resumption of Fe limitation during the Holocene caused an increase in the instantaneous ratio of $\mathrm{Si} / \mathrm{N}$ uptake in diatoms, which in turn caused an increase in the seasonal Si/N removal ratio and thus the opposite behavior of the isotope records (Brzezinski et al., 2002; Beucher et al., 2007).

Based on the behavior of DSi and NOx in the modern Southern Ocean, we suggest that instead the proxies indicate that at the LGM in the Atlantic sector the silicate pump was not as strong relative to the biological pumping of particulate organic matter as it has been in the Holocene. This might still be related to Fe fertilization that resulted in less heavily silicified diatoms at the LGM, or it may be tied to other ecological and physical influences on the efficiency of the silicate pump.

This may seem like a minor point to quibble, but it requires a shift in focus away from the primary production of materials, one big fallacy in our thinking about the biological pump and biogeochemical cycling in the past. What happens to particles after they have been produced is likely to have the greater impact on the distribution of nutrients and dissolved inorganic carbon in seawater.

\section{$4.2 \delta^{30} \mathrm{Si}$ of surface water}

During the first half of ANTXXIII/9, as the cruise progressed from the Weddell Gyre, eastwards along the ice shelf (south of the Southern Boundary of the ACC) and then back into the ACC, the $\delta^{30} \mathrm{Si}$ of DSi in surface water increased in concert with the decrease in DSi concentrations (Fig. 4; Table 2), moving from $+1.4 \%$ in early February up to $+2.5 \%$ in the first week of March. Values of DSi and $\delta^{30}$ Si remained fairly steady until March 26 when, at the northern end of the Fawn Trough, between $56.42^{\circ} \mathrm{S}, 77.15^{\circ} \mathrm{E}$ (sample 44) and $56.07^{\circ} \mathrm{S}$, $76.21^{\circ} \mathrm{E}$ (sample 45), DSi concentrations dropped abruptly from $29 \mu \mathrm{M}$ to $19 \mu \mathrm{M}$ (Fig. $4 \mathrm{~d}$; Table 2). This, together with the simultaneous shift in temperature and salinity from $1.4^{\circ} \mathrm{C}$ and 33.8 psu to $1.6^{\circ} \mathrm{C}$ and 33.6 psu at sampling sites separated in time by 3 hours (data not shown), suggests a crossing over or into the Fawn Trough Current (Roquet et al., 2009). 
From this point in the cruise on, further decrease in DSi concentrations did not correspond to an increase in $\delta^{30} \mathrm{Si}$ (Fig. 4; Fig. 5). In fact, $\delta^{30} \mathrm{Si}$ values remained below $+2 \%$, even as concentrations approached exhaustion. This is completely counter to expectations given the fractionation of silicon isotopes during the uptake of DSi by diatoms (De La Rocha et al., 1997). Samples from portions of the Kerguelen Plateau with a shallow seafloor (250 to 770 $\mathrm{m}$ ) in particular had low $\delta^{30} \mathrm{Si}$ values for their DSi concentration (Fig. 5).

This point is made more clearly by Fig 5 . Samples containing more than $20 \mu \mathrm{M}$ DSi fall along a straight line $\left(\delta^{30} \mathrm{Si}=-0.02 x+2.63 ; r^{2}=0.80, n=30\right)$ when plotted against DSi concentrations, while samples containing less than $20 \mu \mathrm{M}$ DSi often fall below this line. Unexpectedly low $\delta^{30} \mathrm{Si}$ values have been previously observed for samples from the Kerguelen Plateau (Fripiat et al., 2011). These low values may be related to the recycling of silica skewing the relationship between DSi and $\delta^{30} \mathrm{Si}$ at low concentrations of DSi. It is known that silicon isotopes are fractionated during the dissolution of biogenic silica, resulting in the release of DSi with a $\delta^{30} \mathrm{Si}$ value lower than that of the biogenic silica that is dissolving (Demarest et al., 2009). Repeated cycles of partial dissolution in the euphotic zone followed by export of the partially dissolved silica could result in the retention of DSi of low $\delta^{30} \mathrm{Si}$ in the euphotic zone. It may be that this "recycled" DSi with low $\delta^{30} \mathrm{Si}$ predominates the pool of DSi at low concentrations.

Nonetheless, the notable relationship between DSi concentrations and $\delta^{30} \mathrm{Si}$ in open water south of the Antarctic Polar Front lends confidence to the paleoceanographic reconstructions that have been carried out to date in the Atlantic and Indian sectors of the Southern Ocean: over the growing season, as $\delta^{30} \mathrm{Si}$ does indeed appear to track net DSi removal. On the other hand, the agreement with the result of Fripiat et al (2011) for the anomalously low values of $\delta^{30} \mathrm{Si}$ on the Kerguelen Plateau indicate that it will be difficult to carry out accurate paleoceanographic reconstructions from $\delta^{30} \mathrm{Si}$ in areas of restricted water flow and/or intense recycling of silica.

\subsection{Estimation of silicon isotope fractionation}

Together, the concentrations and $\delta^{30} \mathrm{Si}$ of DSi can be used to estimate the fractionation of silicon isotopes occurring during BSi formation (De La Rocha et al., 2000a; Varela et al., 2004; Cardinal et al., 2005; Reynolds et al., 2006). Two different end-member estimates can be made. The first, or "closed system" estimate assumes that one input of DSi to surface waters occurs at the beginning of the growing season, and is in fact a model more suited to tracking the changes in $\delta^{30} \mathrm{Si}$ during a single bloom episode. In this model, the isotopic difference between the BSi produced and the initial $\delta^{30} \mathrm{Si}$ of the DSi can be estimated from the slope of a plot of the $\delta^{30} \mathrm{Si}$ of DSi versus the natural log of DSi (Barford et al., 1999; Sigman et al., 1999; De La Rocha et al., 2000a; Varela et al., 2004). The lower panel of Fig. 6 shows that the samples containing more than $20 \mu \mathrm{M}$ DSi indeed fall along a straight line $\left(r^{2}\right.$ $=0.78 ; n=30$ ) and the slope of $-0.7 \pm 0.07 \%$ suggests that the Southern Ocean diatoms are producing $\mathrm{BSi}$ with a $\delta^{30} \mathrm{Si}$ that is $0.7 \%$ more negative than their DSi source. This value is lower than the estimates of -1.0 to $-1.9 \%$ o that have been made previously for temperate diatoms in culture (De La Rocha et al., 1997; Milligan et al., 2004) and for DSi removal by diatoms growing in surface waters of the Southern Ocean (Varela et al., 2004; Fripiat et al., 2011). It is a closer match to the estimate of $-0.9 \%$ made by Cardinal et al. (2005) based on water column profiles in the Pacific sector.

The other estimate of fractionation can be made using an open system model that assumes the continuous input of DSi to surface waters (and its continuous removal through biogenic silica production) throughout the growing season. By not restricting inputs to a single one which is followed by an uninterrupted period of productivity, this model should be more 
accurate than the closed system model in most areas of the ocean. In this model, $\delta^{30} \mathrm{Si}$ of DSi is plotted against the ratio of the observed concentration of DSi to that at the beginning of the season (Barford et al., 1999; Sigman et al., 1999; Varela et al., 2004), in this case assumed to be $75 \mu \mathrm{M}$, a typical DSi in winter water (WW). The value of $75 \mu \mathrm{M}$ is also close to our highest measured DSi concentrations of 72-76 $\mu \mathrm{M}$ in the surface waters of the Weddell Gyre (Fig. 2; Table 1). This also produced a straight line $\left(r^{2}=0.81 ; n=30\right)$ and yielded an estimate for fractionation of $-1.2 \pm 0.11 \%$ (Fig. 6). Because it is fairly unrealistic to assume a single input of DSi to the euphotic zone each year, we take this estimate of -1.2 \% to be closer to the exact extent of fractionation during diatom production of BSi in the Atlantic and Indian sectors of the Southern Ocean. It also agrees strongly with the estimate of $-1.2 \%$ of Fripiat et al (2011) for the ACC.

It should be noted that if a higher initial concentration of DSi is used the absolute value of the fractionation would be greater. For example, if an initial concentration of $85 \mu \mathrm{M}$ is used, the estimate of fractionation would be $-1.4 \%$ instead of $-1.2 \%$.

\subsection{Comparison with other data}

The $\delta^{30} \mathrm{Si}$ of DSi in surface waters in the Atlantic and Indian sectors of the Southern Ocean reported here can be compared with previously published data from surface waters and depth profiles in the Pacific sector of the Southern Ocean (Fig. 7). The previously published surface water data (the grey circles on Fig. 7) have nicely demonstrated that the $\delta^{30} \mathrm{Si}$ of DSi increases from +1.5 to $+3.0 \%$ from south to north across the Antarctic Polar Front while DSi concentrations decrease due to greater consumption by diatoms (Varela et al., 2004). The depth profile data (reported here as $\delta^{30} \mathrm{Si}$ by multiplication of the reported $\delta^{29} \mathrm{Si}$ values by 1.93) revealed that deepwater in the Southern Ocean has a $\delta^{30} \mathrm{Si}$ centered around $+1.2 \%$ (Cardinal et al., 2005; 2007).

Surface waters sampled in the Atlantic and Indian sectors from open water south of the Antarctic Polar Front (samples 3-44) during ANTXXIII/9 (the black circles on Fig. 7) plot in almost perfect accordance with the surface water data of Varela et al (2004) from the Pacific sector (the grey circles on Fig. 7). However, like the surface waters from the Pacific sector, they plot slightly above the depth profile data of Cardinal et al $(2005 ; 2007)$ from the Pacific sector (the white symbols on Fig. 7). This offset may reflect that the relationship between $\delta^{30} \mathrm{Si}$ and DSi concentrations in surface waters is predominantly controlled by fractionation during biological uptake, but that in the upper few hundred meters of depth profiles, fractionation of silicon isotopes during the dissolution of biogenic silica (Demarest et al., 2009) may be adding back DSi with a lower than expected $\delta^{30} \mathrm{Si}$. During dissolution, the heavier isotopes of silicon are preferentially retained in the solid phase, lending DSi regenerated from $\mathrm{BSi}$ a lower than expected $\delta^{30} \mathrm{Si}$ value. Because the depth profiles should contain a greater proportion of this "regenerated" DSi than the surface waters, on the plot of $\delta^{30} \mathrm{Si}$ versus DSi concentrations, they could plot below the curve defined by the surface water samples. This effect of fractionation during dissolution is also probably why the samples from the shallow areas of the Kerguelen Plateau (the grey circles on Fig. 5) have $\delta^{30}$ Si values that are most notably low for their DSi content (as also pointed out by Fripiat et al., 2011).

\subsection{Implications for the interpretation of Si isotopes in sediment cores}

The concordance of the surface water data from the Atlantic and Indian sectors with that from the Pacific sector (Fig. 7) raises the possibility that, at least in open water areas of the modern Southern Ocean, DSi utilization can be modeled from $\delta^{30}$ Si using single values for fractionation and for the $\delta^{30} \mathrm{Si}$ of DSi supplied to the euphotic zone. For instance, combining 
samples 3-31, 33-44 from this study with the surface water samples of Varela et al (2004) and again assuming that the supplied DSi was initially at $75 \mu \mathrm{M}$ yields an open system estimate for fractionation of $-1.4 \pm 0.09 \%\left(r^{2}=0.76 ; n=72\right)$ (Fig. 8). The regression equation can further be used to calculate the average $\delta^{30} \mathrm{Si}$ of DSi upwelling into the euphotic zone (i.e. $2.8+1.0(-1.4)=+1.4 \%$ ). The $+1.4 \%$ obtained is similar to the values observed for Winter Water by Cardinal et al (2005) and Fripiat et al (2011).

Given the correspondence of the numbers between the three studies that between them covered a massive area of the Southern Ocean, there is some value in trying to model the percent utilization of DSi from previously published values of $\delta^{30} \mathrm{Si}$ from diatom silica in sediment cores, as has been done by Beucher et al (2007). We have repeated this exercise with two Antarctic cores from the Atlantic sector for which diatom $\delta^{30} \mathrm{Si}$ records have been published (De La Rocha et al., 1998; Brzezinski et al., 2002) using the open system model, a fractionation of $-1.4 \%$, and an initial isotopic composition of the DSi of +1.4 \%o (Fig. 9). This yields estimates for the extent of the lowering of surface water DSi concentrations of more than $60 \%$ of the initial upwelled concentration during the Holocene. At the Last Glacial Maximum (LGM), 20,000 years ago, the estimate for the percent removal of DSi drops to the neighborhood of $25 \%$. In general, the estimates for the glacial portions of the two records greater than $50 \%$ draw down of silicic acid concentrations. These results are quite closely comparable to those of Beucher et al (2007) although we used slightly different values for fractionation and the concentration and isotopic composition of the initial DSi. Given the number of uncertainties that remain, however, concerning initial values of DSi concentrations and $\delta^{30} \mathrm{Si}$ in the past, fractionation during dissolution, and given the simplicity of the open system model, none of these estimates should be considered exact.

To highlight one cause for concern, some of the Holocene values estimated from the core RC13-259 yield values slightly greater than 100\% utilization of DSi (Fig. 9b). This occurs when the $\delta^{30} \mathrm{Si}$ of the core exceeds $+1.4 \%$, the absolute value of the fractionation in this case where the initial $\delta^{30} \mathrm{Si}$ is taken to be $+1.4 \%$. This may reflect the limitations of using such a simple model to convert from $\delta^{30} \mathrm{Si}$ and nutrient utilization. Alternatively, it may be due to complications from the fractionation of silicon isotopes during biogenic silica dissolution. However, it seems unlikely that the BSi in the sediments has been shifted upwards by much, as this would yield completely untenable estimates of nutrient utilization from the sediment cores. It is clear that truly quantitative estimates for DSi drawdown in the past requires knowledge of the extent to which $\mathrm{Si}$ isotope fractionation during dissolution influences sedimentary records of $\delta^{30} \mathrm{Si}$, something which at the moment remains entirely unknown. 


\section{Acknowledgments}

We thank the captain and crew of the research vessel FS Polarstern; R. Gersonde, $\mathrm{H}$. Hubberton, and the Alfred Wegener Institute for the opportunity to join ANTXXIII/9; and E. Anagnostou, C. Schlosser, S. Kretschmer, P. Sperlich, P. Croot, M. Rutgers van der Loeff, and R. Sherrell for equipment, assistance, and advice; and O. Ragueneau for insightful comments on an early draft of the manuscript, and the associate editor and reviewers for useful reviews. This research was supported by the grants (to CLD) DE 1455/1-1 from the Deutsche Forschungsgemeinschaft (Antarctic Schwerpunkt Programm) in Germany and SIMS (Silicon Isotopes in the Southern Ocean) through the LEFE/CYBER program of the CNRS in France. This study took place during the International Polar Year.

\section{References}

Abelmann A., Gersonde R., Cortese G., Kuhn G., Smetacek V. (2006) Extensive phytoplankton blooms in the Atlantic sector of the glacial Southern Ocean. Paleoceanogr. 21, PA1013, doi: 10.1029/2005PA001199.

Barford C. C., Montoya J. P., Altabet M. A., and Mitchell R. (1999) Steady-state nitrogen isotope effects of $\mathrm{N}_{2}$ and $\mathrm{N}_{2} \mathrm{O}$ production in Paracoccus denitrificans. Appl. Environ. Microbiol. 65, 989-994.

Beucher C. P., Brzezinski M. A., and Crosta X. (2007) Silicic acid dynamics in the glacial sub-Antarctic: implications for the silicic acid leakage hypothesis. Global Biogeochem. Cycles 21, GB3015, doi:10.1029/2006GB002746.

Bradtmiller L. I., Anderson R. F., Fleisher M. Q. , and Burckle L. H. (2007) Opal burial in the equatorial Atlantic Ocean over the last $30 \mathrm{ka}$ : Implications for glacial-interglacial changes in the ocean silicon cycle. Paleoceanogr. 22, PA4216, doi:10.1029/2007PA001443.

Brzezinski M. A. (1985) The Si:C:N ratio of marine diatoms: interspecific variability and the effect of some environmental variables. J. Phycol. 21, 347-357.

Brzezinski M. A., Dickson M.-L., Nelson D. M., and Sambrotto R. (2003) Ratios of Si, C and $\mathrm{N}$ uptake by microplankton in the Southern Ocean. Deep-Sea Res. // 50, 619-633.

Brzezinski M. A., Pride C. J., Franck V. M., Sigman D. M., Sarmiento J. L., Matsumoto K., Gruber N., Rau G. H., and Coale K. H. (2002) A switch from $\mathrm{Si}(\mathrm{OH})_{4}$ to $\mathrm{NO}_{3}{ }^{-}$depletion in the glacial Southern Ocean. Geophys. Res. Lett. 29, 1564, doi:10.1029/2001GL014349.

Cardinal D., Alleman L. Y., de Jong J., Ziegler, K., and André L. (2003) Isotopic composition of silicon measured by multicollector plasma source mass spectrometry in dry plasma mode. J. Anal. At. Spectrom. 18, 213-218.

Cardinal D., Alleman L. Y., Dehairs F., Savoye N., Trull T. W., and André L. (2005) Relevance of silicon isotopes to Si-nutrient utilization and Si-source assessment in Antarctic waters. Global Biogeochem. Cycles 19, GB2007, doi:10.1029/2004GB002364. 
Cardinal D., Savoye N., Trull T. W., Dehairs F., Kopczynska E. E., Fripiat F., Tison J.-L., and André L. (2007) Silicon isotopes in spring Southern Ocean diatoms: large zonal changes despite homogeneity among size fractions. Mar. Chem. 106, 46-62.

Crosta X., Beucher C., Pahnke K., and Brzezinski M. A. (2007) Silicic acid leakage from the Southern Ocean: opposing effects of nutrient uptake and oceanic circulation. Geophys. Res. Lett. 34, L13601, doi:10.1029/2006GL029083.

De La Rocha C. L. (2006) Opal-based isotopic proxies of paleoenvironmental conditions. Global Biogeochem. Cycles 20, GB4S09. doi:10.1029/2005GB002664.

De La Rocha C. L., Brzezinski M. A., and DeNiro M. J. (1996) Purification, recovery, and laser-driven fluorination of silicon from dissolved and particulate silica for the measurement of natural stable isotope abundances. Anal. Chem. 68, 3746-3750.

De La Rocha C. L., Brzezinski M. A., and DeNiro M. J. (1997) Fractionation of silicon isotopes by marine diatoms during biogenic silica formation. Geochim. Cosmochim. Acta 61, 5051-5056.

De La Rocha C. L., Brzezinski M. A., DeNiro M. J., and Shemesh A. (1998) Silicon-isotope composition of diatoms as an indicator of past oceanic change. Nature 395, 680-683.

De La Rocha C. L., Brzezinski M. A. and DeNiro M. J. (2000a) A first look at the distribution of the stable isotopes of silicon in natural waters. Geochim. Cosmochim. Acta 64, 24672477.

De La Rocha C. L., Hutchins D. A., Brzezinski M. A., Zhang Y. (2000b) Effects of iron and zinc deficiency on elemental composition and silica production by diatoms. Mar. Ecol. Prog. Ser. 195, 71-79.

De La Rocha C. L., Ragueneau O., Leynaert A. (2010) Reconsidering the meaning of biogenic silica accumulation rates in the glacial Southern Ocean. In: The Diatoms (Eds. J Smol and E Stoermer. Cambridge University Press. p. 454-461).

De La Rocha C. L., Terbrüggen A., Völker C., Hohn S. (2010b) Response and recovery of Thalassiosira weissflogii to nitrogen and silicon starvation: growth rates, nutrient uptake and C, Si and N content per cell. Mar. Ecol. Prog. Ser. 412, 57-68.

Demarest M. S., Brzezinski M. A., and Beucher C. P. (2009) Fractionation of silicon isotopes during biogenic silica dissolution. Geochim. Cosmochim. Acta 73, 5572-5583.

Dugdale R. C., Wilkerson F. P., and Minas H. J. (1995) The role of a silicate pump in driving new production. Deep-Sea Res. I 42, 697-719.

Engström E., Rodushkin I., Baxter D. C., and Öhlander B. (2006) Chromatographic purification for the determination of dissolved silicon isotopic compositions in natural waters by high-resolution multicollector inductively coupled plasma mass spectrometry. Anal. Chem. 78, 250-257.

Franck V. M., Brzezinski M. A., Coale K. H., and Nelson D. M. (2000) Iron and silicic acid concentrations regulate $\mathrm{Si}$ uptake north and south of the Polar Frontal Zone in the Pacific Sector of the Southern Ocean. Deep-Sea Res. I/ 47, 3315-3338. 
Fripiat F, Cavagna A.-J., Savoye N., Dehairs F., André L., Cardinal D (2011) Isotopic constraints on the Si-biogeochemical cycle of the Antarctic Zone in the Kerguelen area (KEOPS). Mar. Chem. 123, 11-22.

Helmers E., Mart L., Schrems O. (1991) Lead in Atlantic surface waters as a tracer for atmospheric input. Fresenius J. Anal. Chem. 340, 580-584.

Hoffmann L. J., Peeken I., and Lochte K. (2007) Effects of iron on the elemental stoichiometry durin EIFEX and in the diatoms Fragilariopsis kerguelensis and Chaetoceros dichaeta. Biogeosci. 4, 569-579.

Jennings J. C., Jr., Gordon L. I., and Nelson D. M. (1984) Nutrient depletion indicates high primary productivity in the Weddell Sea. Nature 308, 51-54.

Kamykowski D. and Zentara S.-J. (1989) Circumpolar plant nutrient covariation in the Southern Ocean: patterns and processes. Mar. Ecol. Prog. Ser. 58, 101-111.

Klatt O. Fahrbach E., Hoppema M., Rohardt G. (2005) The transport of the Weddell Gyre across the Prime Meridian. Deep-Sea Res. // 52, 513-528.

Matsumoto K., Sarmiento J. L., Brzezinski M. A. (2002) Silicic acid leakage from the Southern Ocean: A possible explanation for glacial atmospheric $\mathrm{pCO}_{2}$. Global Biogeochem. Cycles 16, 10.1029/2001GB001442.

Milligan A. J., Varela D. E., Brzezinski M. A., and Morel F. M. M. (2004) Dynamics of silicon metabolism and silicon isotopic discrimination in a marine diatom as a function of $\mathrm{pCO}_{2}$. Limnol. Oceanogr. 49, 322-329.

Mosseri J., Quéguiner B., Armand L., Cornet-Barthaux V. (2008) Impact of iron on silicon utilization by diatoms in the Southern Ocean: A case study of Si/N cycle decoupling in a naturally iron-enriched area. Deep-Sea Res. // 55, 801-819.

Nelson D. M., Anderson R. F., Barber R. T., Brzezinski M. A., Buesseler K. O., Chase Z., Collier R. W., Dickson M.-L., François R., Hiscock M. R., Honjo S., Marra J., Martin W. R., Sambrotto R. N., Sayles F. L., Sigmon D. E. (2002) Vertical budgets for organic carbon and biogenic silica in the Pacific sector of the Southern Ocean, 1996-1998. Deep-Sea Res. // 49, 1645-1674.

Orsi A. H., Whitworth III T., Nowlin W. D., Jr (1995) On the meridional extent and fronts of the Antarctic Circumpolar Current. Deep-Sea Res. I 42, 641-673.

Pondaven P., Ragueneau O., Tréguer P., Hauvespre A., Dezileau L., and Reyss J. L. (2000) Resolving the 'opal paradox' in the Southern Ocean. Nature 405, 168-172.

Ragueneau O., Dittert N., Pondaven P., Tréguer P., Corrin L. (2002) Si/C decoupling in the world ocean: is the Southern Ocean different? Deep-Sea Res. // 49, 3127-3154.

Ragueneau O., Schultes S., Bidle K., Claquin P., Moriceau B. (2006) Si and C interactions in the world ocean: Importance of ecological processes and implications for the role of diatoms in the biological pump. Global Biogeochem. Cycles 20, GB4S02, doi:10.1029/2006GB002688.

Reynolds B. C., Frank M., and Halliday A. N. (2006) Silicon isotope fractionation during nutrient utilization in the North Pacific. Earth Planet. Sci. Lett. 244, 431-443. 
Roquet F., Park Y.-H., Guinet C., Bailleul F., Charrassin J.-B. (2009) Observations of the Fawn Trough Current over the Kerguelen Plateau from instrumented elephant seals. J. Mar. Sys. 78, 377-393.

Sarmiento J. L., Gruber N., Brzezinski M. A., and Dunne J. P. (2003) High-latitude controls of thermocline nutrients and low latitude biological productivity. Nature 427, 56-60.

Sigman D. M. and Boyle E. A. (2000) Glacial/interglacial variations in atmospheric carbon dioxide. Nature 407, 859-869.

Sigman D. M., Altabet M. A., McCorkle D. C., Francois R., and Fischer G. (1999) The $\delta^{15} \mathrm{~N}$ of nitrate in the Southern Ocean: Consumption of nitrate in surface waters, Global Biogeochem. Cycles 13, 1149- 1166

Smetacek V., Assmy P., and Henjes J. (2004) The role of grazing in structuring Southern Ocean pelagic ecosystems and biogeochemical cycles. Antarct. Sci. 16, 541-558.

Strickland J. D. H. and Parsons T. R. (1972) A Practical Handbook of Seawater Analysis. Fish. Res. Board Canada.

Takeda S. (1998) Influence of iron availability on nutrient consumption ratio of diatoms in oceanic waters. Nature 393, 774-777.

Varela D. E., Pride C. J., and Brzezinski M. J. (2004) Biological fractionation of silicon isotopes in Southern Ocean surface waters. Global Biogeochem. Cycles 18, GB1047, 10.1029/2003GB002140.

van Wijka E. M., Rintoul S. R., Ronai B. M., Williams G. D. (2010) Regional circulation around Heard and McDonald Islands and through the Fawn Trough, central Kerguelen Plateau. Deep-Sea Res. I 57, 653-669. 
Table 1. Mass spectrometer operating conditions.

\begin{tabular}{ll}
\hline $\begin{array}{l}\text { Neptune MC-ICP-MS } \\
\text { resolution }\end{array}$ & medium \\
sensitivity & $\sim 6 \mathrm{~V} \mathrm{ppm}{ }^{-1}$ \\
forward power & $1200 \mathrm{~W}$ \\
accelerating voltage & $10 \mathrm{kV}$ \\
cool gas & $15.5 \mathrm{~L} \mathrm{~min}^{-1}$ \\
auxiliary gas & $0.8 \mathrm{~L} \mathrm{~min}^{-1}$ \\
sample gas & $\sim 1 \mathrm{~L} \mathrm{~min}^{-1}$ \\
sampler cone & standard Ni cone \\
skimmer cone & standard Ni cone \\
desolvator & Apex Q (ESI) \\
nebulizer & $60 \mu$ min $^{-1} \mathrm{PFA}$ \\
& microconcentric \\
\hline
\end{tabular}


Table 2. Data for surface water samples from ANTXXIII/9

\begin{tabular}{|c|c|c|c|c|c|c|c|c|c|c|c|c|}
\hline No. & Date & I.D. & Lat. & Long. & $\begin{array}{c}\text { Seafloor } \\
(\mathrm{mbsl})\end{array}$ & $\begin{array}{l}\text { NOx } \\
(\mu \mathrm{M})\end{array}$ & $\begin{array}{l}\mathrm{PO}_{4} \\
(\mu \mathrm{M})\end{array}$ & $\begin{array}{c}\text { DSi } \\
(\mu \mathrm{M})\end{array}$ & $\begin{array}{c}\text { chl a } \\
\left(\mu g L^{-1}\right)\end{array}$ & $\begin{array}{c}\text { BSi } \\
\left(\mu \mathrm{mol} \mathrm{L}{ }^{-1}\right)\end{array}$ & $\begin{array}{c}\delta^{30} \mathrm{Si} \\
(\%)\end{array}$ & $\begin{array}{c}\delta^{29} \mathrm{Si} \\
(\% \mathrm{o})\end{array}$ \\
\hline 1 & 5-Feb-07 & DP & -58.474 & -57.451 & 3950 & 23.3 & 1.68 & 15.9 & 0.1 & 0.4 & 1.85 & 0.98 \\
\hline 2 & 5-Feb-07 & DP & -60.012 & -55.389 & 3610 & 24.5 & 1.68 & 40.7 & 1.7 & 0.6 & 1.53 & 0.81 \\
\hline 3 & 5-Feb-07 & WG & -61.064 & -53.341 & 2008 & 28.4 & 1.69 & 71.9 & 1.7 & 0.5 & 1.51 & 0.80 \\
\hline 4 & 5-Feb-07 & WG & -62.025 & -51.675 & 3093 & 24.8 & 1.93 & 59.4 & 0.5 & 1.5 & 1.88 & 0.90 \\
\hline 5 & 6-Feb-07 & WG & -63.460 & -48.543 & 3399 & 24.7 & 1.71 & 73.7 & & 0.3 & 1.60 & 0.82 \\
\hline 6 & 6-Feb-07 & WG & -63.948 & -46.965 & 3239 & 24.5 & 1.74 & 72.8 & 0.1 & 0.4 & 1.42 & 0.72 \\
\hline 7 & 6-Feb-07 & WG & -64.507 & -45.119 & 4530 & 25.9 & 1.65 & 70.8 & 0.2 & 3.0 & 1.46 & 0.74 \\
\hline 8 & 7-Feb-07 & WG & -65.875 & -40.428 & 4540 & 27.2 & 1.47 & 75.1 & 0.1 & 3.8 & & \\
\hline 9 & 7-Feb-07 & WG & -66.393 & -37.955 & 4634 & 27.5 & 1.75 & 75.6 & 0.1 & 1.7 & & \\
\hline 10 & 7-Feb-07 & WG & -66.725 & -36.222 & 4658 & 27.6 & 1.83 & 74.5 & 0.1 & 3.2 & 1.65 & 0.93 \\
\hline 11 & 8-Feb-07 & WG & -67.477 & -30.594 & 4656 & 28.0 & 1.73 & 75.9 & 0.1 & 0.6 & & \\
\hline 12 & 8-Feb-07 & WG & -67.657 & -28.346 & 4724 & 27.3 & 1.96 & 73.8 & 0.1 & 0.5 & & \\
\hline 13 & 9-Feb-07 & WG & -68.118 & -22.498 & 4898 & 25.5 & 1.91 & 66.4 & 0.5 & 3.8 & & \\
\hline 14 & 9-Feb-07 & WG & -68.343 & -19.598 & 4881 & 26.5 & 1.69 & 65.6 & 0.6 & 2.1 & 1.43 & 0.75 \\
\hline 15 & 9-Feb-07 & WG & -68.582 & -16.496 & 4861 & 20.8 & 1.66 & 69.2 & 0.2 & 1.9 & 1.52 & 0.77 \\
\hline 16 & 10-Feb-07 & WG & -69.045 & -10.381 & 4567 & 27.3 & 1.63 & 71.3 & 0.3 & 1.8 & 1.41 & 0.73 \\
\hline 17 & 10-Feb-07 & WG & -69.980 & -7.444 & 3625 & 27.4 & 1.92 & 68.2 & 0.4 & 2.5 & 1.59 & 0.80 \\
\hline 18 & 14-Feb-07 & $S$ of $S B$ & -69.945 & -3.788 & 2364 & 23.4 & 1.90 & 54.0 & 0.3 & 1.6 & 1.62 & 0.86 \\
\hline 19 & 15-Feb-07 & $S$ of $S B$ & -69.350 & 5.037 & 2267 & 25.7 & 1.65 & 55.4 & 0.4 & 2.7 & 1.77 & 0.91 \\
\hline 20 & 17-Feb-07 & $S$ of $S B$ & -68.028 & 23.464 & 4066 & 22.4 & 1.64 & 48.6 & 0.3 & 2.2 & 2.05 & 1.02 \\
\hline 21 & 17-Feb-07 & $S$ of $S B$ & -67.926 & 25.868 & 3840 & 24.0 & 1.42 & 46.5 & 0.2 & 1.0 & 2.17 & 1.12 \\
\hline 22 & 18-Feb-07 & $S$ of $S B$ & -67.479 & 36.258 & 3309 & 28.0 & 1.65 & 53.9 & 0.1 & 1.0 & 1.77 & 0.92 \\
\hline 23 & 18-Feb-07 & $S$ of $S B$ & -67.393 & 38.239 & 4227 & 28.2 & 1.91 & 55.1 & 0.1 & 0.9 & 1.74 & 0.95 \\
\hline 24 & 20-Feb-07 & $S$ of $S B$ & -65.415 & 50.279 & 2647 & 28.0 & 1.91 & 47.7 & 0.6 & 2.1 & 1.83 & 0.98 \\
\hline 25 & 23-Feb-07 & $S$ of $S B$ & -67.130 & 73.175 & 546 & 17.8 & 1.92 & 36.5 & 5.3 & 4.1 & 1.98 & 0.97 \\
\hline 26 & 3-Mar-07 & AASW & -61.032 & 72.720 & 7192 & 25.6 & 1.15 & 24.6 & 0.2 & 2.7 & 2.24 & 1.16 \\
\hline 27 & 3-Mar-07 & AASW & -62.057 & 72.720 & 4071 & 24.6 & 1.70 & 21.9 & 0.9 & 5.3 & 2.51 & 1.19 \\
\hline 28 & 4-Mar-07 & AASW & -63.275 & 72.720 & 3951 & 24.7 & 1.56 & 24.9 & 1.5 & 5.6 & 2.38 & 1.13 \\
\hline 29 & 4-Mar-07 & AASW & -63.974 & 72.719 & 3736 & 27.0 & 1.57 & 37.4 & 0.1 & 1.2 & 2.09 & 1.06 \\
\hline 30 & 5-Mar-07 & AASW & -64.957 & 72.720 & 3436 & 25.9 & 1.85 & 33.9 & 0.8 & 4.7 & 2.09 & 1.18 \\
\hline 31 & 8-Mar-07 & AASW & -62.150 & 72.708 & 4041 & 25.4 & 1.68 & 25.5 & 0.7 & 4.4 & 2.17 & 1.06 \\
\hline 32 & 8-Mar-07 & AASW & -61.928 & 72.721 & 4088 & 24.3 & 1.60 & 18.0 & 0.3 & 5.4 & 2.32 & 1.06 \\
\hline
\end{tabular}




\begin{tabular}{|c|c|c|c|c|c|c|c|c|c|c|c|c|}
\hline 33 & 18-Mar-07 & AASW & -64.443 & 82.833 & 3633 & 21.5 & 1.55 & 20.7 & 0.2 & 3.2 & 2.12 & 1.22 \\
\hline 34 & 18-Mar-07 & AASW & -63.537 & 82.833 & 2893 & 24.4 & 1.43 & 22.7 & 0.2 & 3.8 & & \\
\hline 35 & 19-Mar-07 & AASW & -61.975 & 82.833 & 2493 & 25.2 & 1.59 & 28.8 & 0.1 & 2.0 & 2.01 & 1.02 \\
\hline 36 & 22-Mar-07 & AASW & -63.523 & 82.834 & 2856 & 24.9 & 1.73 & 24.4 & 0.2 & 2.3 & 2.32 & 1.19 \\
\hline 37 & 22-Mar-07 & AASW & -62.836 & 82.833 & 2324 & 25.3 & 1.56 & 28.8 & 0.3 & 1.9 & & \\
\hline 38 & 23-Mar-07 & AASW & -60.881 & 83.737 & 1586 & 24.4 & 1.69 & 27.5 & 0.1 & 1.0 & & \\
\hline 39 & 23-Mar-07 & AASW & -60.020 & 84.643 & 2053 & 24.6 & 1.68 & 25.6 & 0.1 & 1.9 & 1.91 & 0.95 \\
\hline 40 & 24-Mar-07 & AASW & -59.382 & 85.194 & 4467 & 24.3 & 1.65 & 33.1 & 0.2 & 1.8 & 2.09 & 0.92 \\
\hline 41 & 25-Mar-07 & AASW & -58.764 & 82.859 & 1999 & 26.5 & 1.60 & 26.4 & 0.1 & 1.7 & & \\
\hline 42 & 25-Mar-07 & AASW & -58.081 & 81.298 & 1746 & 27.9 & 1.76 & 39.3 & 0.1 & 1.8 & & \\
\hline 43 & 25-Mar-07 & AASW & -57.565 & 80.138 & 1754 & 26.3 & 1.81 & 29.1 & 0.1 & 2.8 & & \\
\hline 44 & 26-Mar-07 & AASW & -56.421 & 77.154 & 2429 & 27.1 & 1.68 & 29.3 & 0.1 & 2.0 & 2.48 & 1.32 \\
\hline 45 & 26-Mar-07 & AASW & -56.074 & 76.209 & 2982 & 26.1 & 1.77 & 19.1 & 0.1 & 5.3 & 2.44 & 1.22 \\
\hline 46 & 26-Mar-07 & AASW & -55.810 & 75.495 & 3038 & 26.1 & 1.67 & 19.0 & 0.1 & 1.6 & & \\
\hline 47 & 26-Mar-07 & AASW & -55.510 & 74.689 & 3119 & 26.6 & 1.67 & 11.8 & 0.1 & 1.8 & 2.07 & 0.99 \\
\hline 48 & 26-Mar-07 & AASW & -55.221 & 73.917 & 2290 & 26.7 & 1.68 & 10.3 & 0.2 & 1.2 & & \\
\hline 49 & 27-Mar-07 & AASW & -54.254 & 73.661 & 2030 & 26.7 & 1.74 & 12.1 & 0.2 & 0.8 & 2.33 & 1.18 \\
\hline 50 & 27-Mar-07 & AASW & -53.617 & 73.937 & 1781 & 26.7 & 1.71 & 11.4 & 0.2 & 0.9 & 2.31 & 1.06 \\
\hline 51 & 27-Mar-07 & AASW & -53.175 & 74.126 & 273 & 26.8 & 1.59 & 14.1 & 0.4 & 1.5 & 1.84 & 0.93 \\
\hline 52 & 27-Mar-07 & AASW & -52.302 & 74.261 & 250 & 27.5 & 1.70 & 16.5 & 0.5 & 1.5 & 1.74 & 0.85 \\
\hline 53 & 28-Mar-07 & AASW & -50.683 & 72.469 & 549 & 24.7 & 1.82 & 6.2 & 1.3 & 1.9 & 1.86 & 0.89 \\
\hline 54 & 28-Mar-07 & AASW & -50.345 & 71.650 & 560 & 24.8 & 1.70 & 6.1 & 0.3 & 2.1 & & \\
\hline 55 & 30-Mar-07 & AASW & -50.036 & 66.674 & 2299 & 25.6 & 1.61 & 4.3 & 0.2 & 1.5 & 1.93 & 0.97 \\
\hline 57 & 30-Mar-07 & AASW & -49.882 & 64.922 & 281 & 25.8 & 1.63 & 6.6 & 0.2 & 0.6 & & \\
\hline 58 & 30-Mar-07 & AASW & -49.789 & 63.879 & 717 & 25.2 & 1.66 & 4.4 & 0.2 & 0.5 & 1.91 & 0.95 \\
\hline 59 & 31-Mar-07 & AASW & -49.633 & 62.154 & 4039 & 23.8 & 1.62 & 0.4 & 0.1 & 0.4 & & \\
\hline 61 & 31-Mar-07 & SAF-PF & -48.564 & 60.213 & 4465 & 22.6 & 1.56 & 2.6 & 0.1 & 0.2 & & \\
\hline 62 & 1-Apr-07 & SAF-PF & -47.244 & 57.962 & 4450 & 19.8 & 1.51 & 1.0 & 0.3 & 0.2 & & \\
\hline 63 & 1-Apr-07 & SASW & -46.110 & 55.909 & 4178 & 19.7 & 1.23 & 1.0 & 0.4 & 0.2 & & \\
\hline 64 & 2-Apr-07 & SASW & -45.109 & 54.132 & 3574 & 22.1 & 1.29 & 1.2 & 0.3 & 0.2 & & \\
\hline 65 & 2-Apr-07 & SASW & -44.113 & 52.394 & 3444 & 18.3 & 1.34 & 0.1 & 0.3 & 0.2 & & \\
\hline 66 & 3-Apr-07 & SASW & -42.962 & 47.706 & 3151 & 18.5 & 1.21 & 0.5 & 0.2 & 0.2 & & \\
\hline 67 & 4-Apr-07 & SASW & -42.673 & 44.858 & 3087 & 18.4 & 1.17 & 0.6 & 0.2 & 0.1 & & \\
\hline 68 & 4-Apr-07 & SASW & -42.388 & 42.067 & 3567 & 5.3 & 1.13 & & 0.5 & 0.1 & & \\
\hline 69 & 5-Apr-07 & SASW & -42.100 & 39.250 & 3034 & 11.7 & 0.44 & & 0.6 & 0.1 & & \\
\hline 70 & 5-Apr-07 & STSW & -41.423 & 36.973 & 4509 & 6.1 & 0.80 & & 0.6 & 0.1 & & \\
\hline 71 & 6-Apr-07 & STSW & -41.280 & 34.469 & 5038 & 0.1 & 0.51 & 0.1 & 0.3 & 0.4 & & \\
\hline
\end{tabular}




\section{Figures}

Fig. 1. A) Cruise track of F.S. Polarstern cruise ANTXXIII/9. The cruise began at the end of January 2007 in Punta Arenas, Chile and ended in the middle of April 2007 in Cape Town, South Africa. Fronts and boundaries (Orsi et al., 1995) shown are the Subtropical Front (STF) in white, the Subantarctic Front (SAF) in pink, the Polar Front (PF) in yellow, the Southern ACC Front (SACCF) in green, and the Southern Boundary of the ACC (SB) in black. Points shown are the surface water sampling locations. B) The latitude of sampling points versus the date of sampling. White stars represent samples from the Drake Passage (DP), white circles represent samples taken between the Polar Front (PF) and the Southern Boundary of the ACC (SB). Black triangles are samples from the Weddell Gyre (WG) and grey triangles are other samples from south of the SB. Black diamonds are samples from between the Subantarctic Front (SAF) and the PF. Grey circles are samples from between the Subtropical Front (STF) and the SAF. White diamonds are samples from north of the STF.

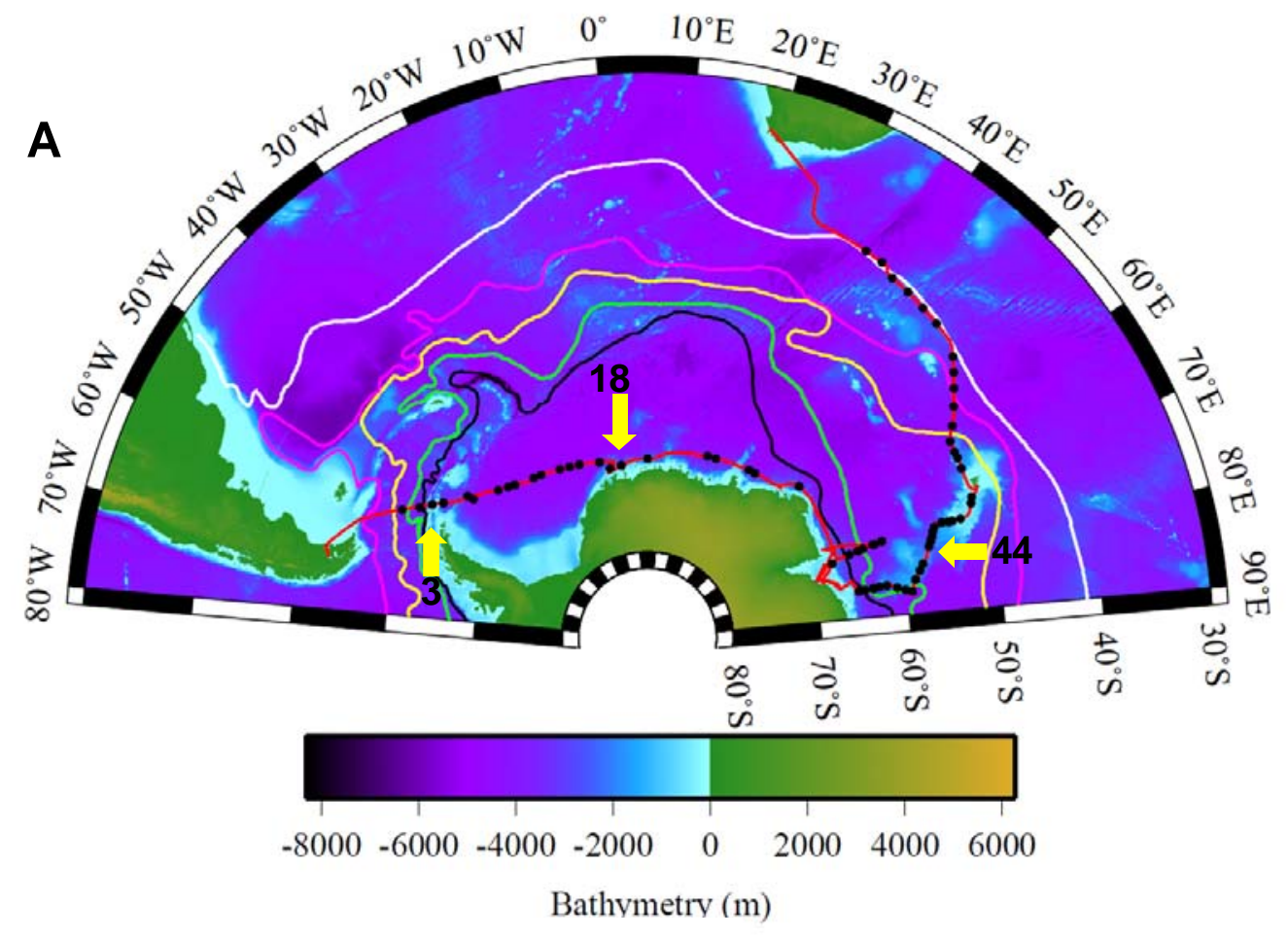

B
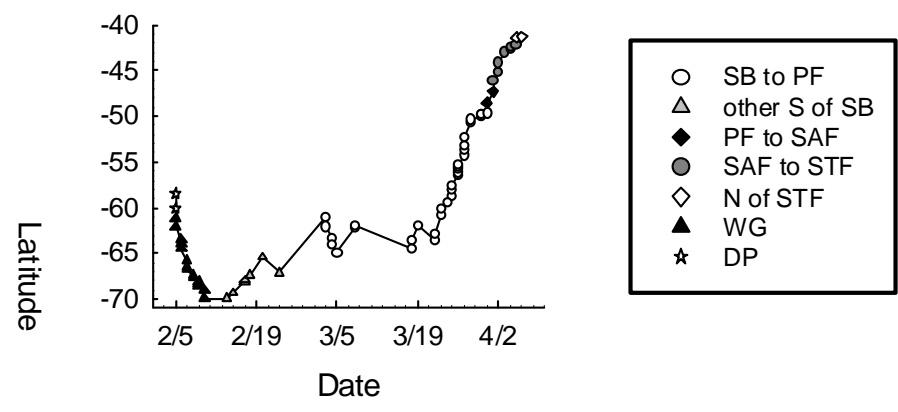

Date 
Fig. 2. Concentrations of dissolved silicon (DSi) versus $A$ ) date and $D$ ) latitude, of nitrate plus nitrite (NOx) versus $\mathrm{B}$ ) date and $\mathrm{E}$ ) latitude, and phosphate by $\mathrm{C}$ ) date and $\mathrm{F}$ ) latitude. Symbols are as in Fig. 1b.
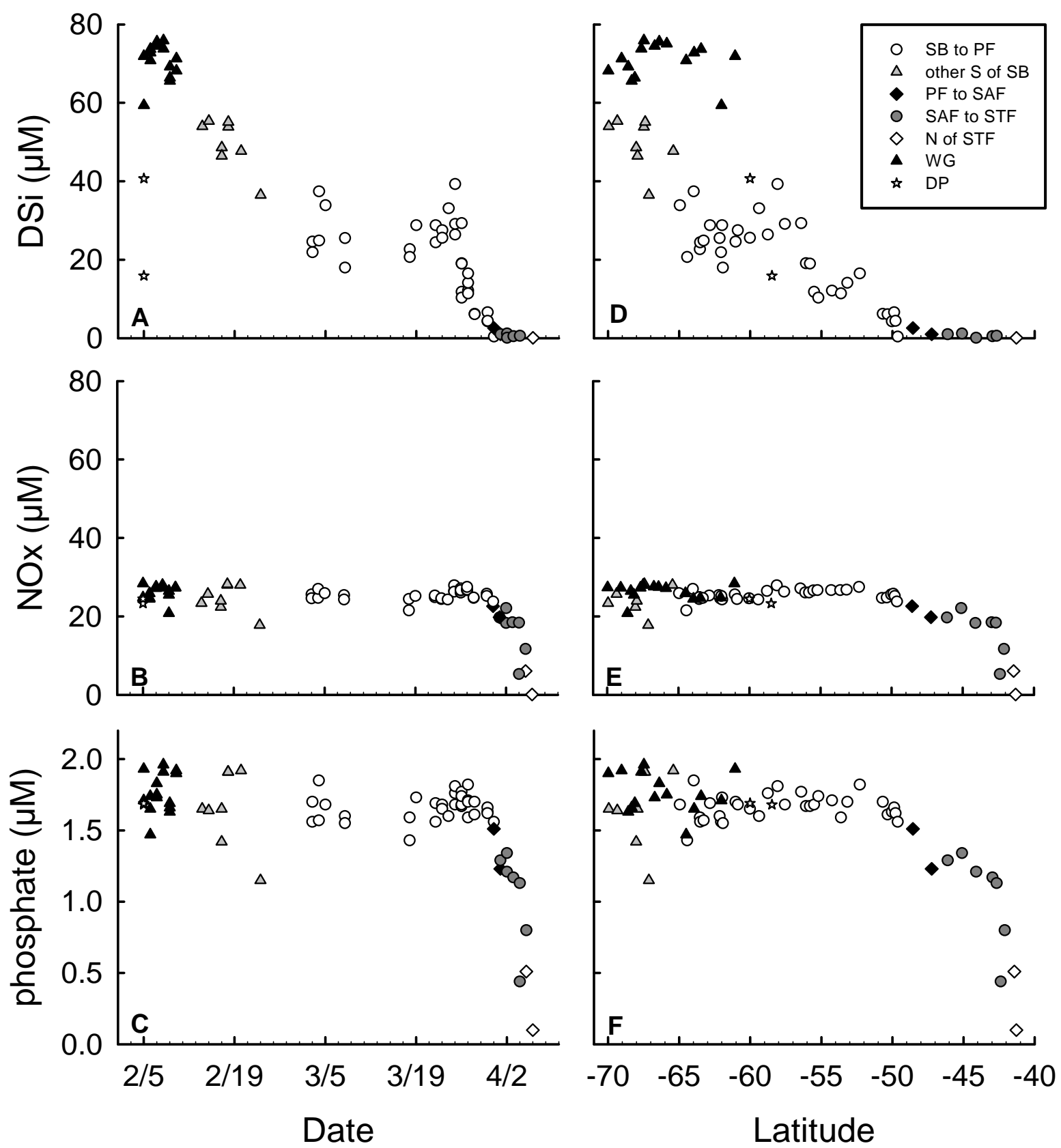
Fig. 3. Concentrations of biogenic silica plotted versus A) date and C) latitude and of chlorophyll a versus B) date and D) latitude. Symbols are as in Fig. 1 b.
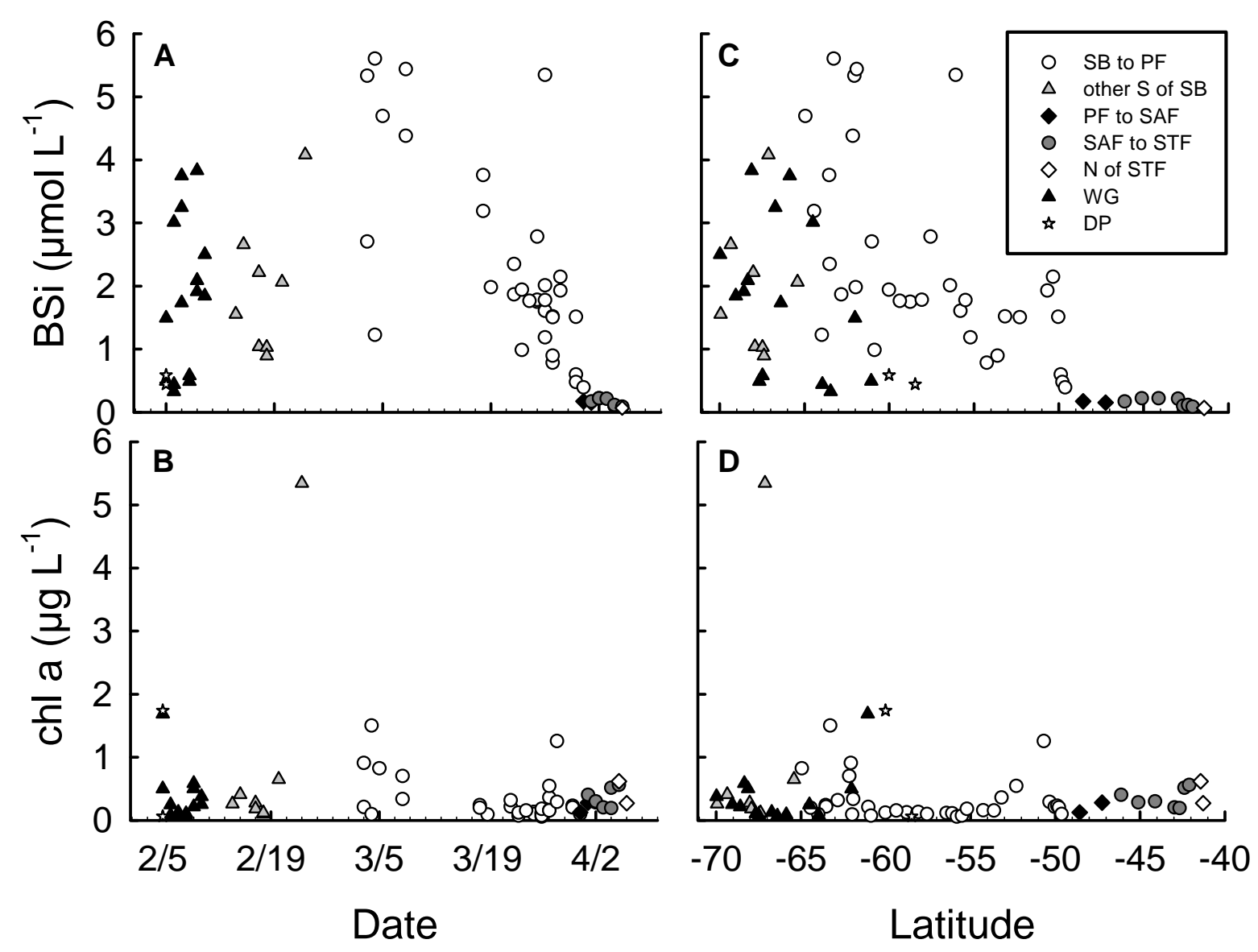
Fig. 4. The silicon isotopic composition $\left(\delta^{30} \mathrm{Si}\right)$ of dissolved silicon in surface water during ANTXXIII/9 plotted $A$ ) versus date and C) versus latitude. Concentrations of DSi are shown again in panels B) and D) for comparison. Symbols are as in Figure $1 \mathrm{~b}$.

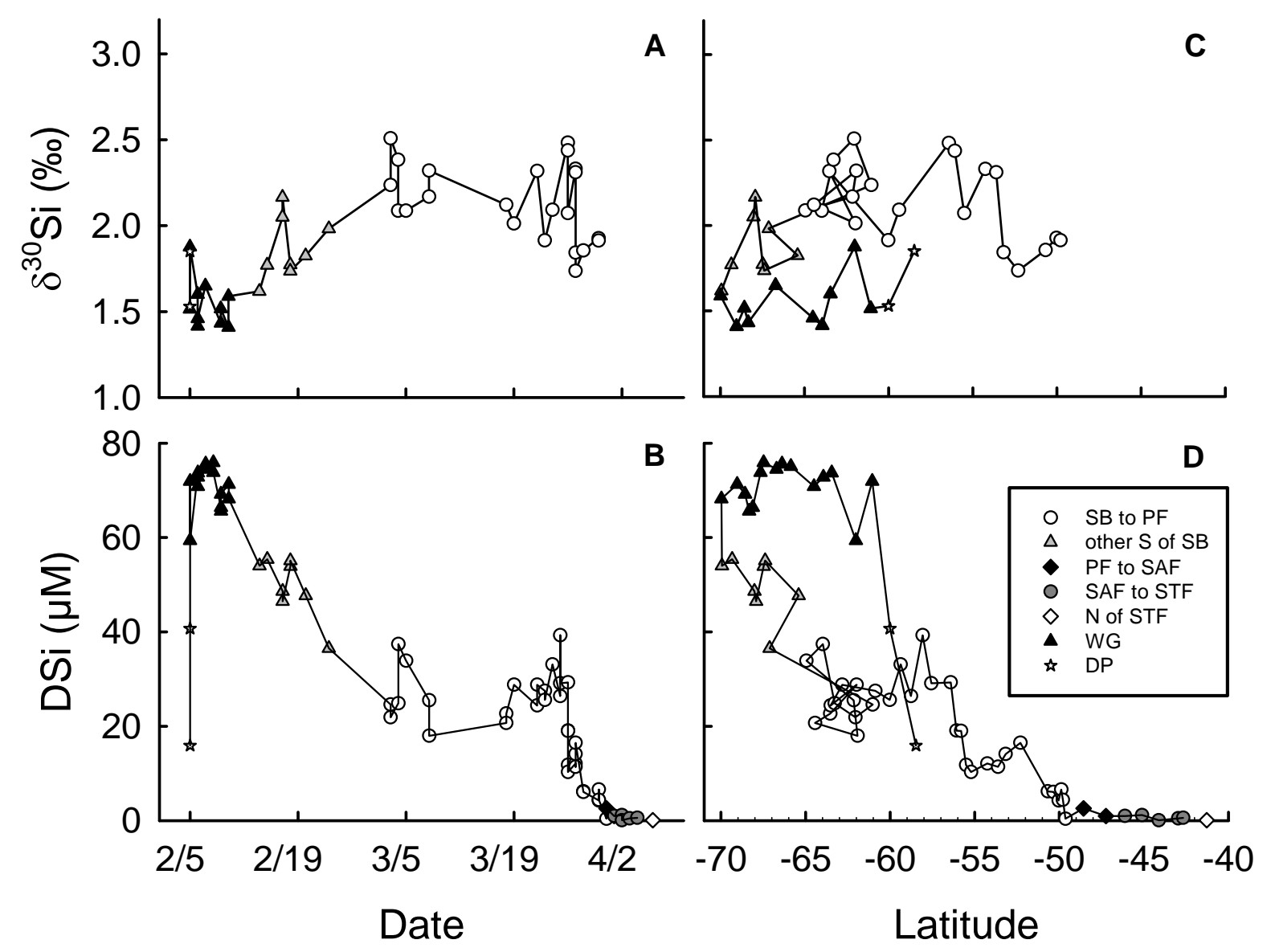


Fig. 5. $\delta^{30}$ Si plotted against DSi concentration. Symbols are as in Fig. 1b, except that dark grey circles indicate samples taken from areas of the Kerguelen Plateau where the seafloor was less than $750 \mathrm{~m}$ deep. The grey box highlights samples containing less than $20 \mu \mathrm{M}$ DSi. The regression line shown for samples (excluding one from the Drake Passage) with DSi concentrations greater than $20 \mu \mathrm{M}$ is $\delta^{30} \mathrm{Si}=-0.02 \mathrm{x}+2.63\left(r^{2}=0.80, \mathrm{n}=30\right)$. The error on the slope is \pm 0.001 .

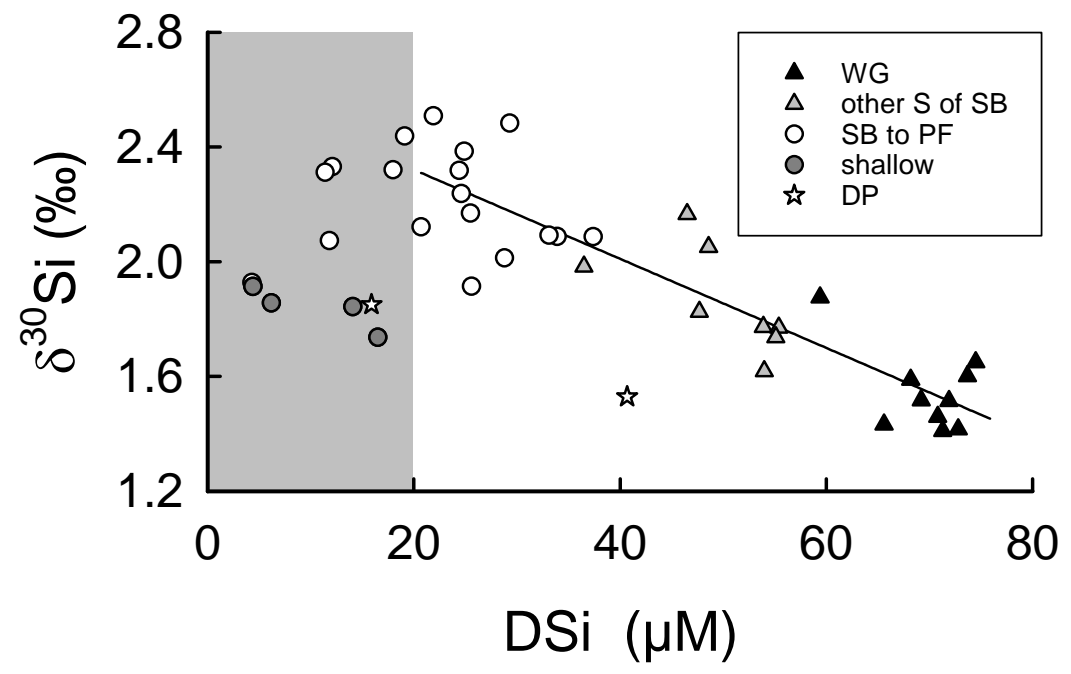


Fig. 6. Silicon isotope fractionation $(\varepsilon)$ estimated for samples 3-31 and 33-44 (i.e. those containing more than $20 \mu \mathrm{M} \mathrm{DSi}$ ) using both A) an open system model and B) a closed system model. The regressions shown are based on 40 samples and the slope of the line in each panel yields the estimate of $\varepsilon$ for each case, or $-1.2 \pm 0.11 \%$ for the open system and $0.7 \pm 0.07 \%$ for the closed system.
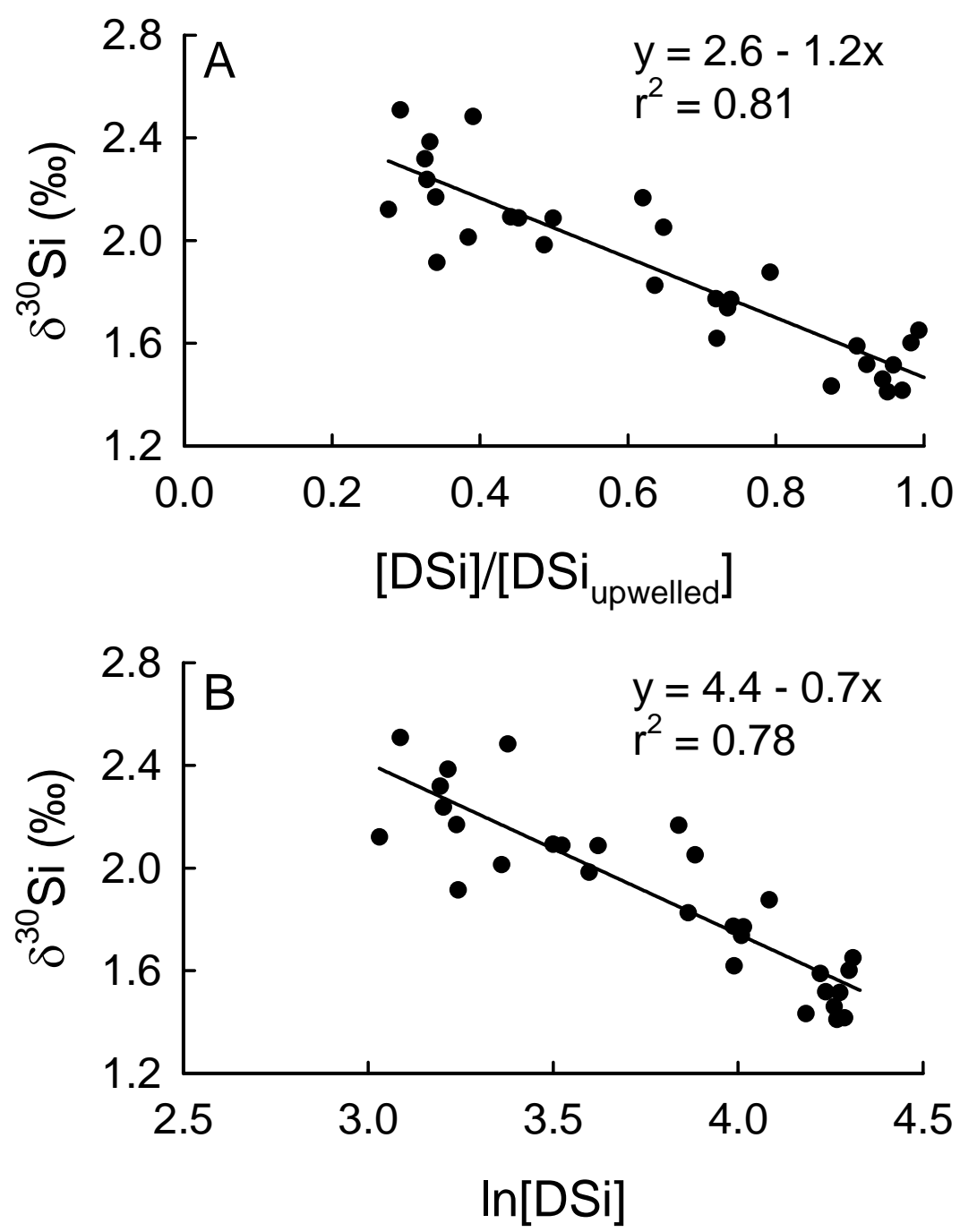
Fig. 7. $\delta^{30} \mathrm{Si}$ versus DSi concentration throughout the Southern Ocean. White triangles (inverted and regular), squares, and diamonds represent depth profile data from the Pacific sector (Cardinal et al., 2005; 2007). Grey circles are surface water data from the Pacific sector (Varela et al., 2004). Grey stars are data from the Ross Sea (De La Rocha et al., 2000). Black circles are samples 3-31, 33-44 from this study and crosses are the other samples reported in this study.

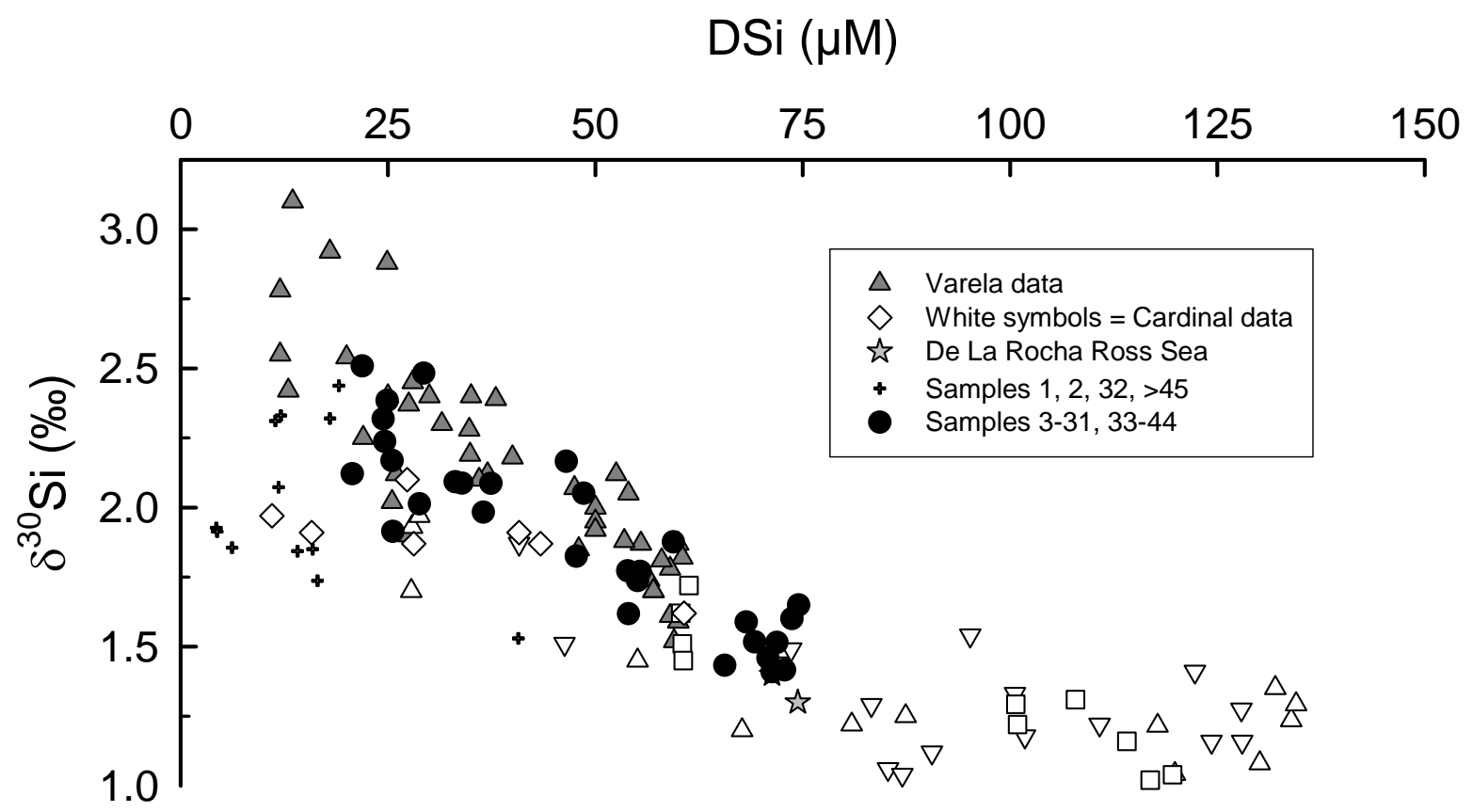


Fig. 8. Silicon isotope fractionation $(\varepsilon)$ in the Southern Ocean as a whole estimated from 72 surface water samples (samples 3-31, 33-44 from this study plus the surface water samples from the Pacific sector of the Southern Ocean (Varela et al., 2004)) using the open system model. The slope of the regression shown is $-1.4 \pm 0.09$.

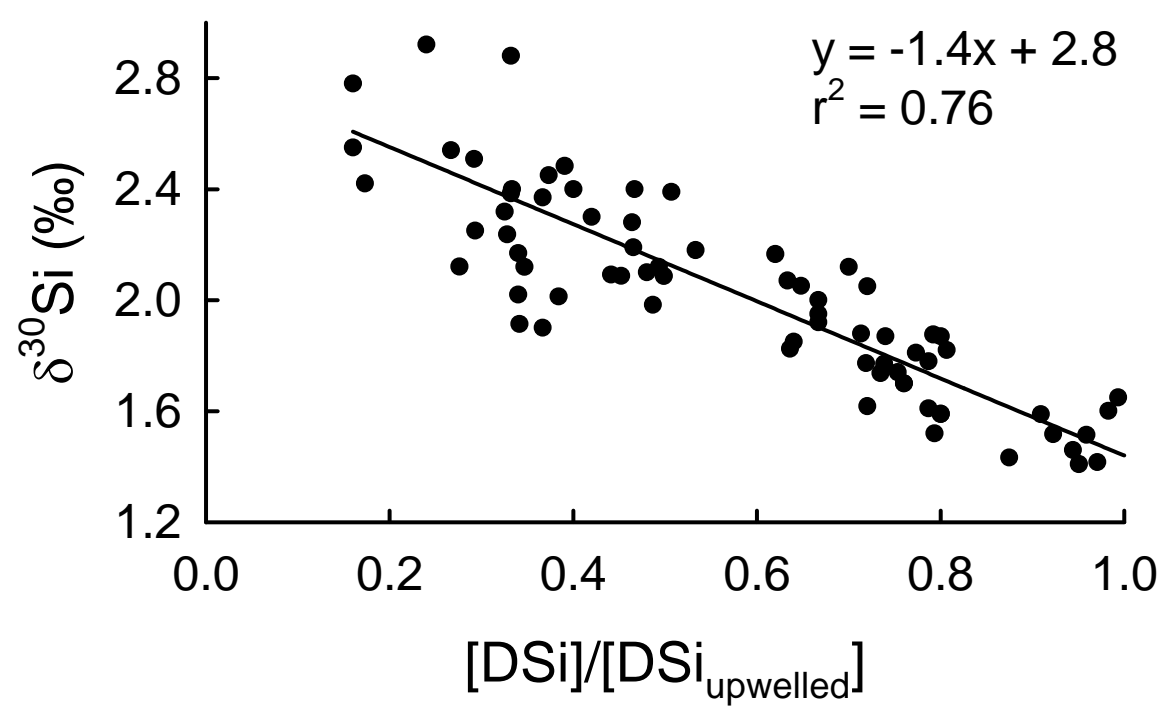


Fig. 9. A) The $\delta^{30} \mathrm{Si}$ of diatom BSi from 2 sediment cores from the Atlantic sector of the Southern Ocean, RC13-259 (white circles) (Brzezinski et al., 2002) and RC13-269 (black circles) (De La Rocha et al., 1998). B) The extent of the drawdown of DSi concentrations by the end of the growing season estimated using the open system model, an $\varepsilon$ of $-1.4 \%$, and an initial value for the $\delta^{30} \mathrm{Si}$ of DSi of $+1.4 \%$. White triangles are the estimates from RC13259 and the black triangles are those from RC13-269. Please note the reversed scale on the y-axis.

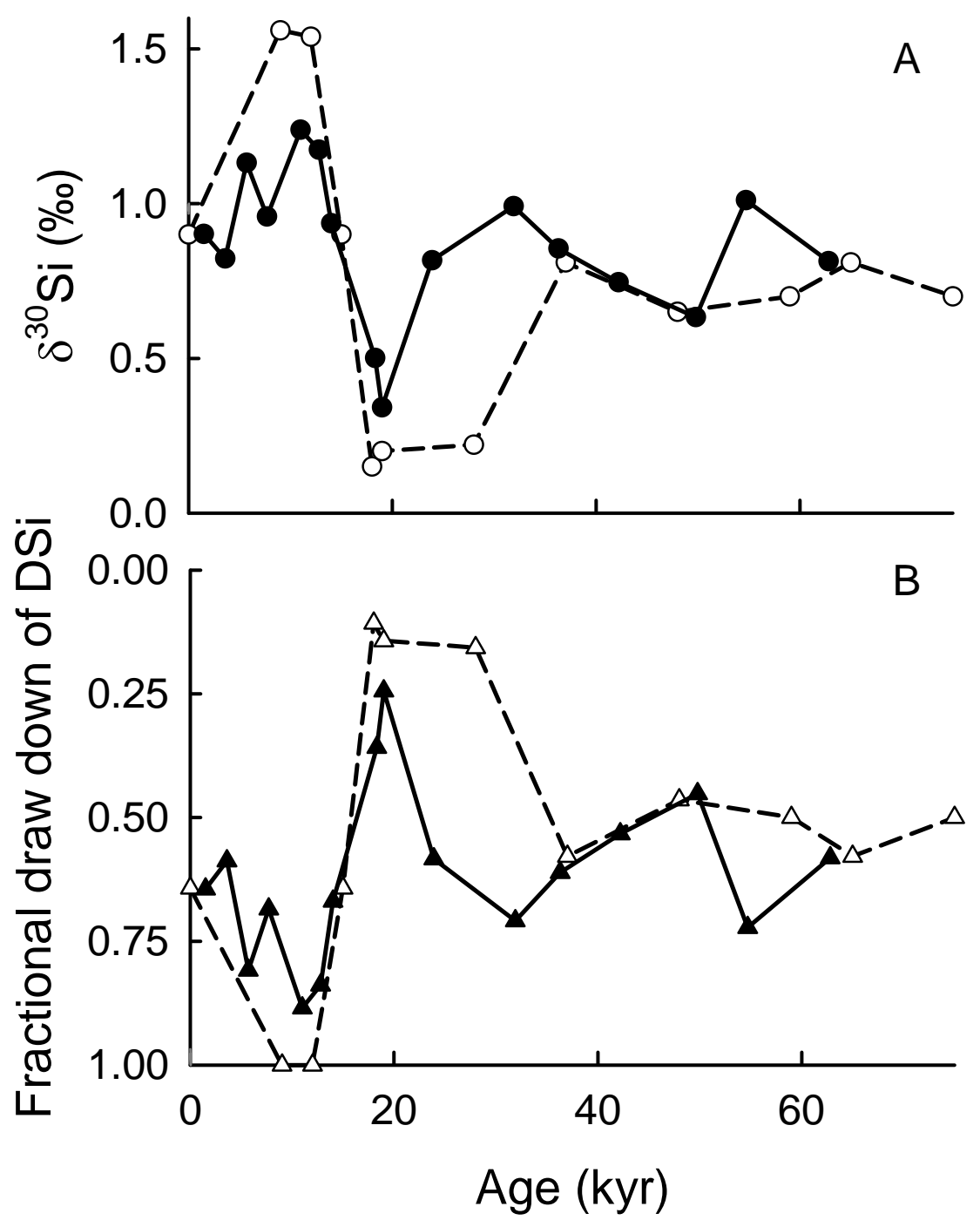

